\title{
Desentralisasi Fiskal \\ Sebagai Bentuk Perimbangan Keuangan Pemerintah Pusat \\ Kepada Daerah
}

\author{
Oleh : \\ Indarto Waluyo \\ FISE UNY
}

\begin{abstract}
Abstrak
Reformasi yang terjadi di era tahun 90 an mendorong keinginan pemberian wewenaing yang lebih luas dari pemerintah pusat kepada daerah untuk mengelola keuangannya sendiri. Laporan bank dunia tahun 1999 mengemukakan bahwa terjadi gerakan-gerakan lokalisasi di sejumlah Negara. lokalisasi yang mencerminkan hasrat lebih besar dari penduduk setempat untuk lebih banyak turut bersuara dalam pemerintahan, mewujudkannya dalam bentuk tuntutan akan identitas daerah. Hal ini mendorong pemerintah nasional untuk memberikan desentralisasi yang lebih luas kepada pemerintah daerah dan kota sebagai cara yang terbaik untuk mengatur dan menangani perubahan-perubahan yang mempengaruhi politik domestik dan pola pertumbuhan

Pemerintah Indonesia merespon dengan mengeluarkan separangkat paket kebijakan reformasi dalam bidang keuangan daerah, dimulai dari dikeluarkannya UU No. 22/1999 tentang Pemerintahan Daerah yang kemudian disempumakan dalam UU No. 32/2004 dan UU No. 25/1999 tentang Perimbangan Keuangan Pemerintah Pusat Dan Daerah yang kemudian disempumakan dalam UU No. 33/2004.

Dengan diberlakukannnya paket kebijakan pemerintah tersebut, anggaran yang dikelola oleh pemerintah pusat merigalami penurunan yang cukup signifikan $(29,8 \%)$ dan pada saat yang sama anggaran yang dikelola oleh daerah naik 25,2\%. Dengan adanya hal tersebut diharapkan agar masyarakat dapat menikmati fasilitas publik dalam jumlah dan kualitas yang sama dan berimbang dengan cara pedesentralisasian urusan disertai dengan pendeseritralisasian pembiayaan. Selain itu, pemenintah daerah secara demokratis dapat menentukan dan mengatur sendin berbagai pelayanan dan kebutuhannya tanpa intervensi yang dalam dari pusat.
\end{abstract}

Kata kunci : Desentralisasi Fiskal, Perimbangan Keuangan Pusat

Pendahuluan

Laporan Bank Dunia tahun 1999/2000 mengemukakan bahwa terdapat perubahan di beberapa belahan dunia sampai pada gerakan yang memicu pada dua 
gejala, yakni : giobalisasi dan lokalisasi. Aspek lokalisasi yang mencermink.an hasrat lebih besar dari penduduk setempat untuk lebih banyak turut bersuara dalam pemerintahan, mewujudkannya dalam bentuk tuntutan akan identitas daerah. Hal ini mendorong pemerintah nasional untuk memberikan desentralisasi yang lebih luas kepada pemerintah daerah dan kota sebagai cara yang terbaik untuk mengatur dan menangani perubahan-perubahan yang mempengaruhi politik domestik dan pola pertumbuhan. (Rustian Kamaludin ; 2000)

Lokalisasi dipandang sesuai dalam rangka menaikkan tingkat partisipasi masyarakat setempat dalam pengambilan keputusan serta memberikan kesempatan yang lebih besar kepada rakyat untuk mendorong keadaan kehidupan mereka sendiri yang lebih baik. Dengan mendesentralisasikan pemerintahan, pengambilan keputusan akan lebih banyak dibuat pada tingkat sub nasional, lebih dekat dengan rakyat dan terciptanya pemerintahan yang reponsif dan efisien.

Namun pergerakan lokaiisasi tersebut bila dilakukan secara tak terkontrol akan bisa membahayakan stabilitas perekonomian nasional dan disintegrasi bangsa. Misalnya pemerintahan daerah yang melakukan pinjaman untuk pendanaan APBD melalui penerbitan obligasi daerah dalam jumlah yang besar dan melakukan pembelanjaan yang kurang bijaksana akan mengganggu stabilitas perekonomian nasional. Tuntutan ke arah pemisahan diri dari NKRI sering diwacanakan di beberapa daerah seperti Aceh, Papua, dan Riau yang akan mengganggu integritas bangsa Indonesia.

Awal tahun 2000 an, akibat dari perkembangan gerakan lokalisasi dan diperkuat dengan adanya gelombang reformasi yang terjadi di Indonesia, telah membuka hati dan pikiran para penyelenggara negara dan wakil-wakil rakyat kita untuk memberikan otonomi yang lebih luas dan nyata kepada deerah yang dilaksanakan daiam kerangka $\mathrm{Ne}$ gara Kesatuan Republik Indonesia. Hal ini tercermin dalam UU No: 22/1999 tentang Pemerintah Daerah (yang kemudian disempurnakan dengan UU No: 32 tahun 2004), serta UU No: 25/1999 tentang Perimbangan Keuangan Pusat dan Daerah (yang kemudian disempurnakan dengan UU No: 33 tahun 2004).

\section{Ketimpangan Antar Daerah}

Ukuran kesenjangan antar daerah dapat dilihat dari perhitungan index Williamson. Index ini menggunakan PDRB (Produk Domestik Regional Bruto) per kapita dalam kaitannya dengan jumlah penduduk per daerah, dengan rumus : 


$$
V w=\sqrt{\frac{\sum i\left(Y_{i}-Y\right)^{2} f_{i} / n}{Y}}
$$

di mana: $V w=$ indeks Williamson $Y_{i}=$ pendapatan per kapita di propinsi ke-I, $Y=$ pendapatan per kapita ratarata seluruh propinsi, $f_{i}=$ jumlah penduduk di propinsi $\mathrm{I}, \mathrm{n}=$ jumlah penduduk nasional Indonesia

Index Williamson merupakan koefisien persebaran dari rata-rata nilai sebaran yang dihitung berdasarkan estimasi dari nilai PDRB dan penduduk daerah-daerah yang berada pada lingkup wilayah yang diamati. Dari tabel 1 terlihat index Williamson berkisar antara 0,602 sampai dengan 0,752 yang berarti bahwa ketimpangan pendapatan antar daerah di Indonesia adalah masih sangat tinggi, dan bahkan cenderung meningkat.

\begin{tabular}{|c|}
\hline \multicolumn{2}{|c|}{ Tabel 1 } \\
Index Wilson di Indonesia Tahun 1981 s/d Tahun 1998 \\
$\qquad$\begin{tabular}{|c|c|}
\hline Tahun & Index Williamson \\
\hline 1981 & 0,602 \\
\hline 1984 & 0,697 \\
\hline 1987 & 0,637 \\
\hline 1990 & 0,774 \\
\hline 1993 & 0,734 \\
\hline 1995 & 0,715 \\
\hline 1996 & 0,709 \\
\hline 1997 & 0,704 \\
\hline 1998 & 0,752 \\
\hline Sumber : (Rustian Kamaludin ; 2000) \\
\hline
\end{tabular}
\end{tabular}

Kesenjangan dan ketidakadilan antar daerah dapat dilihat juga dari besarnya peranan PDRB dengan migas per propinsi. Dalam tabel 2 terlihat besarnya kontribusi masingmasing daerah dalam pembentukan PDB nasional menurut harga berlaku. Daerah-daerah yang kaya akan sumber daya alam mempunyai kontribusi cukup besar dan menempati urutan cukup tinggi. Sebagai misal Kalimantan Timur $(5,95 \%$ urutan ke-5), Riau $(4,73 \%$ urutan ke-7), Aceh $(2,77 \%$ urutan ke-9), Papua $(2,14 \%$ urutan ke-12). Daerah-daerah tersebut dengan kekayaan sumber daya alamnya telah memberikan kontribusi yang besar terhadap penerimaan negara serta pembentukan PDB nasional, 
namun pada umumnya daerah dan masya-rakatnya masih dalam kondisi

terbelakang dan hidup di bawah garis kemiskinan.

Tabel 2

PDRB dan Migas menurut Harga Berlaku

Per Propinsi, 1995 dan 1998 in : Rp 1.000 .000

\begin{tabular}{|c|l|c|c|c|c|}
\hline \multirow{2}{*}{ No Propinsi } & \multicolumn{2}{|c|}{1995} & \multicolumn{2}{c|}{1998} \\
\cline { 2 - 6 } & & Jumlah & $\%$ & Jumlah & $\%$ \\
\hline 1 & DKI Jakarta & 70.045 .319 & 15,87 & 146.215 .775 & 16,27 \\
\hline 2 & Jawa Barat & 76.198 .786 & 17,26 & 142.763 .786 & 15,89 \\
\hline 3 & Jawa Timur & 65.883 .193 & 14,93 & 136.911 .324 & 15,24 \\
\hline 4 & Jawa Tengah & 46.586 .033 & 10,55 & 84.227 .031 & 9,37 \\
\hline 5 & Kalimantan Timur & 21.619 .609 & 4,90 & 53.486 .093 & 5,95 \\
\hline 6 & Sumatra Utara & 24.630 .522 & 5,58 & 48.331 .728 & 5,38 \\
\hline 7 & Riau & 21.234 .728 & 4,81 & 42.490 .846 & 4,73 \\
\hline 8 & Sumatra Selatan & 14.513 .151 & 3,29 & 32.575 .561 & 3,63 \\
\hline 9 & Aceh & 13.091 .228 & 2,97 & 24.919 .100 & 2,77 \\
\hline 10 & Sulawesi Selatan & 10.377 .324 & 2,35 & 21.950 .764 & 2,44 \\
\hline 11 & Lampung & 8.119 .193 & 1,84 & 19.409 .560 & 2,16 \\
\hline 12 & Papua & 7.014 .034 & 1,59 & 19.263 .706 & 2,14 \\
\hline 13 & Sumatra Barat & 8.267 .123 & 1,87 & 18.052 .294 & 2,01 \\
\hline 14 & Kalimanta Barat & 7.138 .914 & 1,62 & 15.666 .178 & 1,74 \\
\hline 15 & Bali & 7.409 .946 & 1,68 & 13.525 .985 & 1,51 \\
\hline 16 & Kalimantan Selatan & 6.210 .472 & 1,41 & 11.932 .227 & 1,33 \\
\hline 17 & DIY & 5.613 .281 & 1,27 & 9.752 .407 & 1.09 \\
\hline 18 & Sulawesi Utara & 3.792 .494 & 0,86 & 9.267 .126 & 1,03 \\
\hline 19 & Kalimantan Tengah & 4.351 .695 & 0,99 & 8.783 .851 & 0,98 \\
\hline 20 & NTB & 3.465 .970 & 0,79 & 7.784 .900 & 0,87 \\
\hline 21 & Sulawesi Tengah & 2.512 .208 & 0,57 & 6.692 .776 & 0,74 \\
\hline 22 & Jambi & 3.457 .564 & 0,78 & 6.633 .294 & 0,74 \\
\hline 23 & Maluku & 3.171 .107 & 0,72 & 5.270 .836 & 0,59 \\
\hline 24 & NTT & 2.874 .131 & 0,65 & 4.758 .352 & 0,53 \\
\hline 25 & Sulawesi Tenggara & 1.819 .242 & 0,41 & 4.382 .995 & 0,49 \\
\hline 26 & Bengkulu & 1.988 .629 & 0,45 & 3.401 .181 & 0,38 \\
\hline & & & & & \\
\hline Sunyyyyy & & & & \\
\hline
\end{tabular}

Sumber : (Rustian Kamaludin ; 2000) 
Alokasi Dana Pembangunan Dari Pemerintah Pusat Untuk Daerah

Alokasi dana pembangunan dari pemerintah pusat untuk daerah mengalami perubahan sejak diberlakunya Undang-Undang tentang Perimbangan Keuangan Pusat dan Daerah. Dana perimbangan adalah dana yang bersumber dari APBN yang dialokasikan kepada daerah untuk mendanai kebutuhan daerah dalam rangka pelaksanaan desentralisasi. Dana perimbangan terdiri atas :

\section{A. Dana Bagi Hasil}

Dana bagi hasil adalah dana yang bersumber dari pendapatan APBiN yang óialokasikan kepada daerah berdasarkan angka persentase tertentu untuk mendanai kebutuhan daerah dalam rangka pelaksaraan desentralisasi. Dana bagi hasil (DBH) merupakan dana bagian daerah yang bersumber dari penerimaan perpajakan dan penerimaan sumber daya alam.

Dana Bagi hasi! yang bersumber dari pajak terdiri dari :

1. Pajak Bumi dan Bangunan (PBB)

2. Bea Perolehan Hak atas Tanah dan Bangunan (BPHTB)

3. Pajak Penghasilan Wajib Pajak Perorangan Dalam Negeri (PPh WPOPDN)

4. Pajak Penghasilan Pasal 21 (PPh 21)
Dana Bagi hasil yang bersumber dari Sumber Daya Alam terdiri dari

1. Kehutanan

2. Pertambangan Uimum

3. Perikanan

4. Pertambangan Minyak Bumi

5. Pertambangan Gas Bumi

6. Pertambangan Panas Bumi

\section{B. Dana Alokasi Umum}

Dana alokasi umum (DAU) merupakan instrument transfer ke daerah yang berperan untuk meminimumkan ketimpangan fiskal antar daerah, sekaligus memeratakan kemampuan keuangan antar daerah dan dialokasikan dama bentuk block grant. Formula yang digunakan dalam perhitungan DAU adalah konsep kesenjangan fiskal (fiscal gap), yaitu selisih antara kebutuhan fiskal dengan kapasitas fiskal. Dana Alokasi Umum dibutuhkan untuk menutup adanya celah fiskal yarig disebabkan oleh kebutuhan fiskal daerah yang melebihi potensi fiskalnya.

Adapun besaran DAU ditetapkan sekurang-kurangnya $25 \%$ dari penerimaan dalam negeri bersih, dengan rincian $10 \%$ untuk propinsi dan $90 \%$ untuk kabupaten/kota. Untuk meningkatkan fungsi utama DAU sebagai alat pemerataan kemampuan keuangan antar daerah, maka penerapan formula DAU sejak tahun 2003 dilakukan dengan kebijakan sebagai berikut : 
- Sejak tahun 2004 alokasi DAU ditingkatkan yaitu dari $25 \%$ menjadi $25,5 \%$ dari PDN bersih.

- Formula yang digunakan mengacu pada peraturan pemerintah nomer 84 tahun 2001 tentang dana perimbangan.
- Tetap mempertimbangkan faktor penyeimbang yang terdiri dari lumpsum dan proposional terhadap kebutuhan belanja pegawai.

- DAU bagi daerah otonom baru dihitung secara proporsional dari daerah induknya berdasarkan jumlah penduduk, luas wilayah, dan belanja PNS daerah.

Gambar 1

Perhitungan Formula DAU

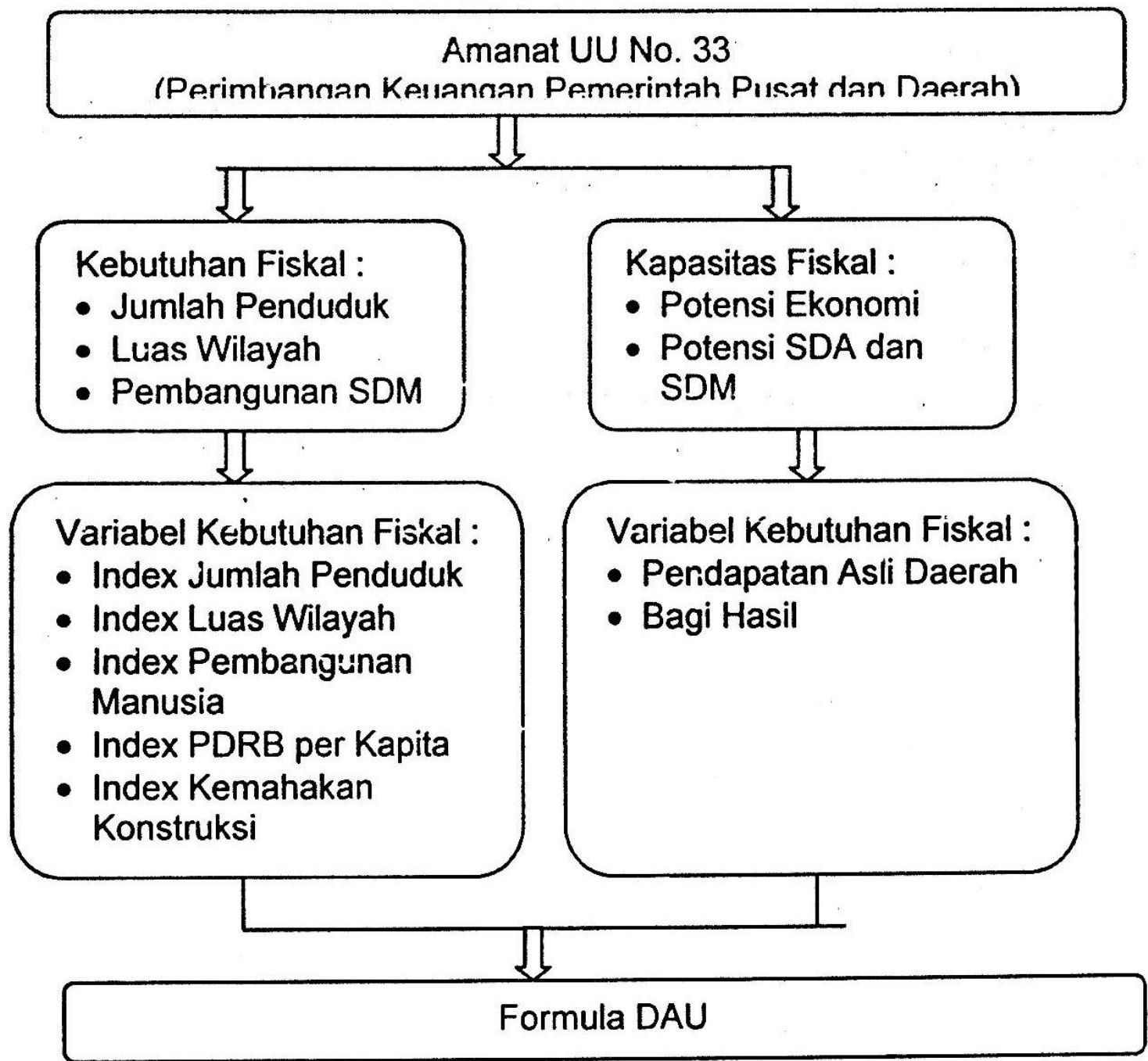

Sumber : DJPKPD, Depkeu 
C. Dana Alokasi Khusus

Selaian Dana Bagi Hasil dan

Dana Alokasi Umum, kepada daerah juga disediakan Dana Alokasi Khusus (DAK) yang digolongkan ke dalam bantuan yang bersifat spesific grant. Pada awalnya DAK yang disedaiakan bagi daerah seluruhnya berasal dari dana reboisasi yang dialokasikan sebesar $40 \%$ dari penerimaannya. Namun, mulai dari tahun 2003 selain untuk membiayai kegiatan reboisasi di daerah penghasil, DAK diberikan juga dalam DAK non dana reboisasi yang disediakan bagi daerah tertentu untuk membiayai kebutuhan khusus seperti :

1. Kebutuhan yang tidak dapat diperkirakan secara umurn dengan menggunakan rumus aloksi umum.

2. kebutuhan yang merupakan komitmen atau prioritas nasional.

DAK dialokasikan kepada daerah tertentu untuk mendanai kegiatan khusus yang merupakan bagian dari program prioritas nasional yang menjadi kewenangan daerah. Besaran DAK ditetapkan setiap tahun dalam APBN. Kegiatan khusus yang ditetapkan oleh pemerintah mengutamakan kegiatan pembangunan, pengadaan, peningkatan, perbaikan sarana dan prasarana fisik pelayanan dasar masyarakat dengan umur ekonomis yang panjang, termasuk pengadaan sarana fisik penunjang.

Daerah tertentu sebagaimana dimaksud diatas adalah daerah yang dapat memperoleh alokasi DAK berdasarkan :

1. Kriteria Umum

Kriteria umum dirumuskan berdasarkan kemampuan keuangan daerah yang dicerminkan dari penerimaan APBD setelah dikurangi belanja pegawai negeri sipil daerah (PNSD)

2. Kriteria Khusus

Kriteria khusus dirumuskan berdasarkan (i) peraturan perundangan yang mengatur penyelenggaraan otonomi khusus, misalnya UU No.21 tahun 2001 teniang otonomi khusus Propinsi Papua serta UU No. 18 tahun 2001 tentang otonomi khusus Propinsi Nanggroe Aceh Darussalam, serta (ii) Kharakteristik daerah.

3. Kriteria Teknis

Kriteria teknis disusun berdasar indicator-indikator kegiatan khusus yang akan didanai dari DAK. Kriteria teknis dirumuskan melalui indeks teknis oleh menteri teknis terkait yang disampaikan kepada menteri keuangan.

Adapun perkembangan alokasi DAU dan DAK terlihat pada tabel 3 di bawah ini : 
Tabel 3

Perkembangan Alokasi DAU dan DAK Tahun 2003 - 2007 (dalam Triliun Rupiah)

\begin{tabular}{|c|c|c|c|c|}
\hline \multirow{2}{*}{ Tahun } & \multicolumn{2}{|c|}{ DAU (Triliun) } & \multicolumn{2}{c|}{ DAK (Triliun) } \\
\cline { 2 - 5 } & Nilai & Pertumbuhan & Nilai & Pertumbuhan \\
\hline 2003 & 77,0 & - & 2,7 & - \\
\hline 2004 & 82,1 & 6,6 & 4,1 & 51,9 \\
\hline 2005 & 88,8 & 8,2 & 4,8 & 17,1 \\
\hline 2005 & 145,6 & 63,9 & 11,6 & 141,7 \\
\hline 2007 & 163,1 & 12,01 & 14,4 & 24,1 \\
\hline
\end{tabular}

Sumber : RAPBN 2007

Gambar 2 menjelaskan secara detail alokasi dana pembangunan yang dilimpahkan pengelolaannya kepada daerah sebagai bukti nyata

pelaksanaan asas desentralisasi fiskal sebagai amanat dari undangundang

Gambar 2

Alokasi Dana APEN ke Daerah Sumber: (Abdul Halim: 2008)

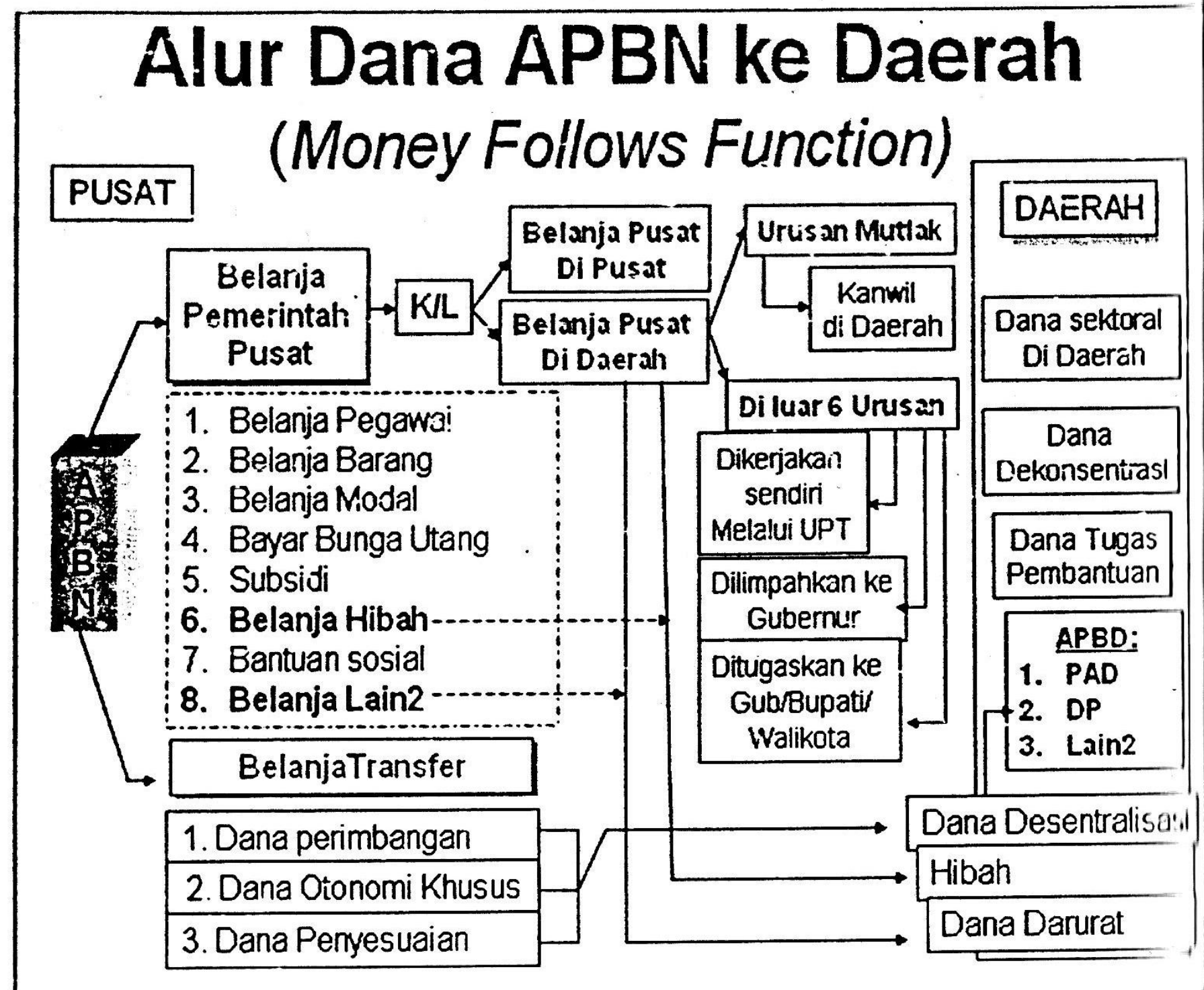


Pelaksanaan desentralisasi fiskal sangat terasa dalam APBN, dalam tabei 4 teriliat adanya pengelolaan anggaran oleh pemerintah daerah dengan porsi yang banyak dari tahun sebelumnya. Anggaran pemerintah daerah tahun 2000 bila dibandingkan dengan tahun 1999/2000 mengalami kenaikan sebesar $25,2 \%$, porsi anggaran yang dikelola daerah telah meningkat pula porsinya dari $30,8 \%$ (1999/2000) menjadi $64,8 \%$ (2000). Di sisi yang lain, anggaran yang dikelola pemerintah pusat mengalami penurunan $29,8 \%$, dengan porsi $29,6 \%(1999 / 2000)$ dan $35,2 \%$ (2000).

Tabel 4

Pengeluaran Pembangunan APBN 1999/2000 Dan RAPBN 2000

(dlm miliar rupiah)

\begin{tabular}{|c|c|c|c|c|c|}
\hline \multirow[t]{2}{*}{ Pengeluaran } & \multicolumn{2}{|c|}{$1999 / 2000(9 \mathrm{bl})$} & \multicolumn{2}{|c|}{$2000(9 \mathrm{~b} !)$} & \multirow[t]{2}{*}{$\%$ prbhn } \\
\hline & Jumih & $\%$ & Jumlh & $\%$ & \\
\hline Anggaran Yg Dikelola Daerah & $12.097,00$ & 30,75 & $\$ 5.139,40$ & 64,82 & 25,15 \\
\hline A. Dana Pembangunan Daerah & $9.920,2$ & 25,22 & $12.546, \overline{70}$ & 53,72 & 26,48 \\
\hline 1. Dana Pembgn Desa & 608,10 & 1,55 & 670,40 & 2,87 & 10,25 \\
\hline 2. Dana Pembgn Kab/Kota & $4.331,30$ & 11,01 & $5.940,00$ & $25, \overline{43}$ & 37,14 \\
\hline 3. Dana Pembgn Propinsi & $2.387,00$ & 6,07 & $3.111,20$ & 13,32 & 30,34 \\
\hline 4. JPS Penanggin Kmiskinan & $2.593,80$ & 6,59 & $2.825,70$ & 12,10 & 8,94 \\
\hline B. Dana dari BH PBB \& BPHTB & $2.176,80$ & 5.53 & $2.692,70$ & 11.53 & 23,70 \\
\hline Anggran Yg Dikelola Pusat & $11.713,5$ & $29, \overline{78}$ & $8.217,50$ & 35,18 & $(29,85)$ \\
\hline A. Departemen / Lembaga & $10.516,90$ & 26,74 & $7.267,50$ & 31,12 & $(30,90)$ \\
\hline 1. Departemen / Lembaga & $9.568,70$ & 24,33 & $6.550,00$ & 23,04 & $(31,55)$ \\
\hline 2. Departemen Hankam & 948,20 & 2,41 & 717,50 & 3,07 & $(24,33)$ \\
\hline B. Lain-lain Pembangunan & $1.196,60$ & 3,04 & $\$ 50,00$ & 4,07 & $(20,61)$ \\
\hline $\begin{array}{l}\text { Anggran u/ subsidi dan } \\
\text { rekonstruksi Perbankan }\end{array}$ & 15.525 .80 & 39,47 & - & - & \\
\hline A. Subsidi Bunga Kredit Program & $2.775,80$ & 7.06 & - & - & - \\
\hline B. Restruturisasi Perbankan & $12.750,00$ & 32,41 & - & - & 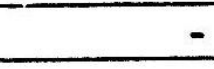 \\
\hline
\end{tabular}

Sumber: (Rustian Kamaludin ; 2000) 


\section{Daftar Pustaka}

Badan Pemeriksa Keuangan. 1995. Standar Audit

Pemerintahan. Jakarta

Badan Pemeriksa Keuangan. 2008. Sistem Pengelolaan Keuangan Pemerintah. Jakarta

Badan Pemeriksa Keuangan. 2008. Hubungan Keuangan Pusat Dan Daerah. Jakarta Bastian, Indra. 2006. Akuntansi Sektor Publik. Erlangga. Jakarta.

Halim, Abdul. 2008. Review

Singkat UU Nomor 33 Tahun 2004. KKD UGM.

Yogvakarta.

Kamaluddin Rustian.2000.

Perimbangan Keuangan

Pusat dan Daerah Dalam Rangka Otonomi Daerah. Jakarta
Wilkinson, JW, and M.J, Cerullo. 2000. Accounting Information Systems. Essential Concepts and Applications. John Wiley and Sons, Inc. New York. 2005. Standar Akuntansi Pemerintahan. PP No: 24 Tahun 2005. 2006. Sistem Akuntansi Instansi. Direktorat Akuntansi dan Pelaporan Keuangan. Departemen Keuangan Republik Indonesia. Jakarta. 2007. Rencana Anggaran Pendapatan \& Belanja Negara 2007.

\section{Biodata Penulis}

Indarto Waluyo adalah salah satu staf pengajar pada Jurusan Pendidikan Akuntansi FISE_UNY 